\title{
Regional Financial Differences in China from the Perspective of Financial Geography
}

\author{
Xiao Ge *, Lingjie Meng \\ School of Economic \& Management Nanjing University of Science and Technology, Nanjing, \\ China \\ *Corresponding author: Xiao Ge, master degree candidate, kongquegongzhu1991@126.com
}

\begin{abstract}
An analysis framework of influential factors to Chinese regional financial development from the perspective of financial geography has been constructed in this paper. Empirical results show that the financial geographical elements of human capital, technological progress, social network and good legal environment promote the development of regional financial. Eastern technology spillovers contribute to its regional financial development. With the development of electronic information technology and social network, regional financial is not dependent on traffic facilities anymore. Moreover, government economic participation can promote the financial development of the western region, but it's not obvious in the western and central regions.
\end{abstract}

Key Words: regional finance; financial geography; economic policy;social network;legal environment

\section{Introduction}

Currently, China has basically established the securities and futures markets, currency markets and foreign currency inter-bank market and realize the diversification of financial market, including commercial banks, social security funds, trust companies, securities companies, insurance companies and other institutions. However, as an economic power,China did not become a financial power. In addition to single financial product, insufficient innovation and increase of non-performing loans, unbalanced development and the gap between regions have become bigger,which are also the dilemmas China faces up with. Therefore, the research on influential factors of Chinese regional differences in financial development and putting forward some policy suggestions have become the core of scholars' research .

In the traditional research process, some scholars ascribe the differences in regional financial development to the traditional geographical factors: geographical location and natural conditions. But traditional theory cannot explain for the phenomenon: some regions where geographical location and natural conditions are not very favorable but own decent financial industry. American scholar Krugman ${ }^{1}$ (1990)suggested that though two regions which natural conditions and geographical location are very close to each other, may be different due to 
some accidental factors (such as historical events) that lead to industry gather in one area. Since then, new economic geography is on the rise. Yeung ${ }^{2}$ (2003) considered that economic, historical, cultural and institutional factors should be taken into consideration. Chinese scholars also try to explain the difference of regional financial development in China from the perspective of financial geography, such as Jin Xuejun, Tian $\operatorname{Lin}^{3}$ (2004), Lu Jia and Jin Xuejun $^{4}$ (2007). The index system covers the economy, culture, science and technology, location, history, policy and other aspects.By the further research, the social capital and the legal environmental factors are also pointed up as important reasons for the differences in regional financial development.French scholar Pierre Bourdieu5(1992) is the first one to elaborated the social capital from the meaning of modernization and divides social capital into economic capital, cultural capital and social capital . He argues that social capital is a kind of social relation network which is more stable, more institutionalized and sustainable and can provide a certain resource. The theory of social capital as a supplement to the new economic growth theory, scholars generally believe that, high level of social capital society means that the social resource network operation is complete, social participation and cooperation is frequent, the transaction costs can be reduced and the market information asymmetry can be improved, that's all will play a certain role in promoting the development of the financial (Guiso $^{6}$, 2001). The research of Zhang Junsheng, Ceng Yamin ${ }^{7}(2005)$ and Cui Wei ${ }^{8}(2013)$ indicated that there is a positive correlation between financial capital and social development. As a Continue and thorough research of the corporate governance on the legal way, legal sources of regional financial has gradually been put forward. The research of La porta, Lopez-de-silanes, Shleifer and Vishny ${ }^{9}(\mathrm{LLSV}, 1998)$ which is most influential and has a pioneering significance, point out that differences in the level of financial development in different countries can be explained by the degree of legal protection of investors based on the legal origin. The study of Deng Hefei and Zheng Zhigang ${ }^{10}(2010)$ shows that: the improvement of the legal environment has a significant impact on the development of regional capital market scale and the scale of bank credit. Chu Liping, Liu Bingyong ${ }^{11}(2015)$ obtains that legal environment has a significant positive effect on both non-life insurance industry and the development of the insurance industry. This paper will select the data of 30 provinces in China from 2002 to 2013 as research objects, enrich and expand the financial geography indicators of the regional financial development and explore the reasons for the differences and put forward the corresponding policy recommendations.

\section{$\mathbf{2}$ The Cross sectional characteristics of the differences in regional financial development} In order to investigate the differences of Chinese regional finance intuitively, we analyzes the characteristics of regional financial development with cross section data. The development of regional finance is not only the growth of the quantity, but also the improvement of the quality and the rationalization of the structure. We take the indicators mainly from two aspects: the scale of financial development, the depth and breadth of financial development. From the view of quantity, the three aspects of banking, securities and insurance namely. The 
development of banks are reflected by the balance of deposits and loans of financial institutions; Reflect the development of insurance market with premium income; Take the number of listing corporation and the total market value of the stock market as the scale index of the stock market. With the number of listing Corporation and the total stock market price index as the scale of the development of the securities market.From the view of quality, we choose the depth and the breadth indexes of the financial development: the finance related degree, insurance depth, insurance density and securitization rate four indicators. the finance related degree, depth and density of insurance and securitization rate four indicators. We take the average data of the annual cross section data between 2011 and 2013 to avoid short-term fluctuations.At the same time, In order to avoid the impact of short-term fluctuations, this paper will conduct a factor analysis on the average annual cross section data data of 30 provinces and cities in China from 2011 to 2013. The results are shown in table I.

Table 1 - factor score of regional financial development level

\begin{tabular}{|l|c|c|c|l|c|c|c|}
\hline PROVINCE & F1 & F2 & F & PROVINCE & F1 & F2 & F \\
\hline Beijing & 0.271 & 1.598 & 1.869 & Chongqing & -0.178 & -0.035 & -0.213 \\
\hline Guangdong & 1.229 & -0.178 & 1.051 & Hunan & -0.066 & -0.166 & -0.232 \\
\hline Shanghai & 0.460 & 0.545 & 1.005 & Xinjiang & -0.276 & 0.033 & -0.243 \\
\hline Zhejiang & 1.196 & -0.301 & 0.896 & Sahnxi & -0.179 & -0.098 & -0.277 \\
\hline Jiangsu & 0.814 & -0.215 & 0.599 & Yunnan & -0.215 & -0.075 & -0.290 \\
\hline Sichuan & -0.151 & 0.538 & 0.387 & Heilongj & -0.215 & -0.083 & -0.298 \\
\hline Shandong & 0.479 & -0.227 & 0.252 & Jilin & -0.165 & -0.138 & -0.303 \\
\hline Liaoning & -0.002 & -0.013 & -0.015 & Gansu & -0.306 & -0.066 & -0.372 \\
\hline Henan & 0.057 & -0.107 & -0.050 & Jiangxi & -0.215 & -0.158 & -0.373 \\
\hline Hebei & 0.035 & -0.087 & -0.052 & Ningxia & -0.463 & 0.070 & -0.393 \\
\hline Fujian & 0.002 & -0.073 & -0.071 & Guizhou & -0.320 & -0.095 & -0.416 \\
\hline Hubei & 0.014 & -0.114 & -0.100 & Guangxi & -0.212 & -0.220 & -0.432 \\
\hline Tianjin & -0.277 & 0.132 & -0.145 & Neimenggu & -0.223 & -0.210 & -0.434 \\
\hline Zhejiang & -0.069 & -0.091 & -0.160 & Hainan & -0.388 & -0.065 & -0.453 \\
\hline Shanxi & -0.209 & 0.015 & -0.194 & Qinghai & -0.428 & -0.116 & -0.544 \\
\hline
\end{tabular}

Three scores and rankings in the table reflect the cross-section differences of financial development of different Chinese provinces and cities. As for the factor score: $\mathrm{F}>0$, representing a higher than the average; $\mathrm{F}<0$, representing a lower than the average level. $\mathrm{F} 1$ indicates the financial development scale score, F2 indicates the width and breadth of the measure.As the Chinese financial center, Beijing and Shanghai, both in the scale or in the depth and breadth of financial development are unique. Banks, securities and insurance development are more balanced; In addition, from the breadth of the level, Zhejiang, Guangdong, Jiangsu, Shandong, Henan, Hebei, Hubei seven provinces are higher than the national average;From the depth of the level, Sichuan, Tianjin, Shanxi, Xinjiang four provinces and cities are above the average level.A clear trend can be seen that the scores will be higher from the west to the east. 


\section{Variable selection and regression analysis}

\subsection{Variable Selection}

In the study of regional finance, more attention is focused on the banking system.This paper chose the explanatory variables from the three branches of banking, insurance, securities industry and financial industry overall . Because of the habit of thrift and saving of Chinese residents, the balance of loans is better than the balance of deposits to reflect the backs' ability to dispose capital and allocate resources. Therefore, we use the ratio of loan balance of financial institutions to its GDP to measure the level of development of bank system.In the view of securities industry and the insurance industry, the ratio of total market value of the stock market and the insurance income to GDP will be selected. The overall development of the financial industry is represented by the degree of financial correlation. Additionally, the financial ratio is loan and deposit balance of financial institutions to the ratio of GDP. For the explanatory variables, we add social capital and Legal environmental factors and make an adjustment and replacement of the corresponding variables on the results of the study of Krugman (1991) et at al.The index is selected as the following table II:

Table II- The measurement index of regional financial development

\begin{tabular}{|c|c|c|}
\hline INDEX & CLASSIFICATION & NOTE \\
\hline \multirow{6}{*}{$\begin{array}{l}\text { Financial } \\
\text { Geography } \\
\text { Environment }\end{array}$} & Human Capital(HC) & $\begin{array}{l}\text { The number of on-school students in the ordinary } \\
\text { colleges and universities per hundred }\end{array}$ \\
\hline & Scientific and Technological（SCI） & $\begin{array}{l}\text { The number of three kinds of patent (invention patent, } \\
\text { utility patent, design) authorized Application }\end{array}$ \\
\hline & Traffic facilities (HW) & Highway mileage \\
\hline & Economic spillover（IND） & Third industrial output value accounted of GDP \\
\hline & $\begin{array}{l}\text { (Consumption)Cultural factors } \\
\text { (CUL) }\end{array}$ & $\begin{array}{l}\text { Consumption of urban residents which are removed } \\
\text { clothing, food, housing consumption accounted for the } \\
\text { ratio of total consumption }\end{array}$ \\
\hline & Social Network（NET） & The ratio of post and telecom business income to GDP \\
\hline $\begin{array}{c}\text { Economic } \\
\text { Policy Factors }\end{array}$ & $\begin{array}{l}\text { Government's involvement in the } \\
\text { economy(POL) }\end{array}$ & $\begin{array}{l}\text { The proportion of the financial expenditure of the } \\
\text { general public affairs and the education . }\end{array}$ \\
\hline $\begin{array}{l}\text { Legal } \\
\text { Environment }\end{array}$ & Efficiency of Law (LAW) & $\begin{array}{l}\text { The number of received administrative reconsideration } \\
\text { accounts for the proportion of GDP. Among them, the } \\
\text { greater the number of variables, the worse the validity } \\
\text { of the law. }\end{array}$ \\
\hline
\end{tabular}

\subsection{Regression Analysis}

Take the results of table III and table IV , we can conclude: 1) Human capital, technological progress, social network relations and good legal environment have a promoting effect to for the development of the eastern, central and western regional financial.2) With the development of electronic information and the multi-channel extension social network relations, the development of the regional finance is no more dependent on transport conditions. 3) The industry spillover of the eastern region significantly promote the 
development of the financial sector. That's because the eastern region industry is relatively more developed compared with the central and western regions and the industrial scale formation and the development of corresponding industries need more perfect financial services, so as to promote the development of the financial. 4) Government economic participation promote the financial development in the west obviously, but not same to the east and the middle, because the overall development of the western is relatively backward, the government's economic participation can play a role of optimizing the allocation of resources and guiding the financial markets.

Table III- The regression results of banking,insurance and securities industry

\begin{tabular}{|c|c|c|c|}
\hline & Banking & Insurance & Security \\
\hline $\mathrm{C}$ & $\begin{array}{c}-0.11157 \\
(-0.40488)\end{array}$ & $\begin{array}{c}2.388143 \\
(1.103155)\end{array}$ & $\begin{array}{l}4.317578 * * \\
(2.533253)\end{array}$ \\
\hline $\mathrm{HC}$ & $\begin{array}{c}0.150029 * * * \\
(2.957907)\end{array}$ & $\begin{array}{c}0.158481 \\
(0.674926)\end{array}$ & $\begin{array}{c}0.000241 \\
(0.019612)\end{array}$ \\
\hline SCI & $\begin{array}{c}\text { 6.82E-07* } \\
(1.802415)\end{array}$ & $\begin{array}{c}1.60 \mathrm{E}-06 \\
(0.788946)\end{array}$ & $\begin{array}{l}\text { 5.55E-06** } \\
(2.595808)\end{array}$ \\
\hline HW & $\begin{array}{l}-9.32 \mathrm{E}-07 * * * \\
(-3.509206)\end{array}$ & $\begin{array}{c}-6.86 \mathrm{E}-06 \\
(-1.331533)\end{array}$ & $\begin{array}{c}-3.60 \mathrm{E}-06 \\
(-0.553466)\end{array}$ \\
\hline IND & $\begin{array}{c}1.885098 * * * \\
(6.083339)\end{array}$ & $\begin{array}{c}0.106759 \\
(0.043095)\end{array}$ & $\begin{array}{c}0.220649 \\
(0.091109)\end{array}$ \\
\hline CUL & $\begin{array}{c}0.893956 * \\
(1.775587)\end{array}$ & $\begin{array}{c}-3.978536 \\
(-1.308922)\end{array}$ & $\begin{array}{l}-7.467287 * * \\
(-2.431289)\end{array}$ \\
\hline NET & $\begin{array}{c}2.78649 * * * \\
(2.99516)\end{array}$ & $\begin{array}{c}0.035585 \\
(0.024394)\end{array}$ & $\begin{array}{c}0.001525 * * * \\
(4.758857)\end{array}$ \\
\hline POL & $\begin{array}{c}0.559428 * * * \\
(2.752376)\end{array}$ & $\begin{array}{c}-2.41783 \\
(-1.192553)\end{array}$ & $\begin{array}{c}-3.897539 * * * \\
(-4.730973)\end{array}$ \\
\hline LAW & $\begin{array}{l}-0.06952 * \\
(-1.70568)\end{array}$ & $\begin{array}{c}-0.46817 \\
(-0.781619)\end{array}$ & $\begin{array}{c}-0.916944 \\
(-1.464640)\end{array}$ \\
\hline $\begin{array}{l}\text { Adjusted } \\
\text { R-squared }\end{array}$ & 0.948495 & 0.972501 & 0.927622 \\
\hline MODEL & FE & FE & $\mathrm{FE}$ \\
\hline
\end{tabular}

a.Due to the lack of some data in the securities market data, so we only taking the data of year 2009 to 2013.

b. '***', '**' and ' *' 'represents $1 \%, 5 \%$ and $10 \%$ of the significant respectively.

Table IV-The regression results of the eastern, central and western regions

\begin{tabular}{|c|c|c|c|c|}
\hline & The East & The Central & The West & The Whole Country \\
\hline \multirow{2}{*}{ C } & $\begin{array}{c}1.127487 \\
(0.97364)\end{array}$ & $\begin{array}{c}1.043664 \\
(0.889656)\end{array}$ & $\begin{array}{c}-0.270103 \\
(-0.209007)\end{array}$ & $\begin{array}{c}0.382757 \\
(0.572657)\end{array}$ \\
\hline \multirow{2}{*}{ HC } & $\begin{array}{c}0.225845 \\
(1.811485)\end{array}$ & $\begin{array}{c}0.039685 \\
(0.175385)\end{array}$ & $\begin{array}{c}0.38235^{* *} \\
(1.370267)\end{array}$ & $\begin{array}{c}0.169523 \\
(1.377942)\end{array}$ \\
\hline \multirow{2}{*}{ SCI } & $1.78 \mathrm{E}-06^{*}$ & $6.31 \mathrm{E}-06$ & $2.73 \mathrm{E}-05$ & $2.55 \mathrm{E}-06^{* * *}$ \\
& $(1.753801)$ & $(1.174649)$ & $(1.376253)$ & $(2.780326)$ \\
\hline \multirow{2}{*}{ HW } & $-2.11 \mathrm{E}-06^{*}$ & $-2.89 \mathrm{E}-06^{* * *}$ & $-1.15 \mathrm{E}-06$ & $-1.56 \mathrm{E}-06^{* *}$ \\
& $(-1.835857)$ & $(-2.843342)$ & $(-1.176151)$ & $(-2.42294)$ \\
\hline \multirow{2}{*}{ IND } & $3.618357^{* * *}$ & -1.471524 & 1.944036 & 1.112403 \\
& $(2.913081)$ & $(-1.051408)$ & $(1.085807)$ & $(1.480008)$ \\
\hline \multirow{2}{*}{ CUL } & -0.110342 & $4.643897 *$ & 2.655469 & $2.287621^{*}$ \\
& $(-0.050225)$ & $(1.959312)$ & $(0.980847)$ & $(1.873285)$ \\
\hline NET & 0.486088 & 4.561765 & 6.830152 & 0.270473 \\
\hline
\end{tabular}




\begin{tabular}{|c|c|c|c|c|}
\hline & $(0.170674)$ & $(0.919215)$ & (1.376145) & $(0.119862)$ \\
\hline POL & $\begin{array}{c}0.452634 \\
(0.482324)\end{array}$ & $\begin{array}{c}0.355136 \\
(0.328113)\end{array}$ & $\begin{array}{l}2.310055^{* *} \\
(2.433555)\end{array}$ & $\begin{array}{l}1.256769 * * \\
(2.549255)\end{array}$ \\
\hline LAW & $\begin{array}{c}-0.158505 \\
(-0.801154)\end{array}$ & $\begin{array}{c}-0.253281 \\
(-1.445576)\end{array}$ & $\begin{array}{c}-0.021767 \\
(-0.115947)\end{array}$ & $\begin{array}{c}-0.035605 \\
(-0.360153)\end{array}$ \\
\hline $\begin{array}{c}\text { Adjusted } \\
\text { R-squared }\end{array}$ & 0.953261 & 0.606654 & 0.416934 & 0.891226 \\
\hline MODEL & $\mathrm{FE}$ & $\mathrm{FE}$ & $\mathrm{FE}$ & $\mathrm{FE}$ \\
\hline
\end{tabular}

\section{Conclusions and policy recommendations}

We can conclude: the financial geographic elements of human capital, technological progress, social network relation and good legal environment have a promoting effect on the development of regional finance and the technology spillover of the eastern region promotes its development of regional finance. With the development of electronic information and the multi-channel extension social network relations, the development of the regional finance is no more dependent on transport conditions. In addition, Government economic participation promotes the western financial development obviously, but not obvious to the east or middle. According to the conclusions of this paper, we propose the following policy proposals:

1)For the areas of financial development which is relatively backward, governments should strengthen its participation in the economic activities actively. While for the areas of financial marketization degree is relatively high, governments should decline its participation in economic activities and make full use of the market self-regulation.

2)Improvement of our legal environment and law enforcement efficiency will be profitable.

\section{References}

1. K. Paul, Increasing returns and economic geography ,R. National Bureau of Economic Research, vol.w3275(1990).

2. H. W. Yeung, G. Lin, Theorizing economic geographies of Asia ,J.Journal of Economic Geography,Vol.79(February,2003)107-128 .

3. X.Jin, L. Tian, Difference of Chinese regional finance growth: 1978-2003,J. Journal of Economic Theory and Economic Management,vol.8(August,2004)24-30.

4. J. Lu, X.J. Jin, Chinese regional financial development : the geographical environment and economic policy - Based on an empirical analysis from the perspective of financial geography ,J.Journal of Financial Theory and Practice, vol.6(June ,2007)7-9.

5. P. Bourdieu, L. J. D. Wacquant, An invitation to reflexive sociology,University of Chicago press,Chicago, 1992.

6. L. Guiso, P. Sapienza, Zingales, Does Local Financial Development Matter, R. Physica-Verlag HD,(2009)31-66.

7. J.S. Zhang, Y. Ceng, Social Capital and Regional Financial Development: An Empirical Research Based on Chinese ,J.Journal of Finance and Economics, vol.31 (April,2005) 37-45.

8. W. Cui, A study on the difference of Chinese regional financial development- From 
the perspective of social capital, J.Journal of Economics,vol.10(March,2013)98-94.

9. F. L. D.E. Silanes, R. L. Porta, A. Shleifer, The Law and finance ,J. Journal of Political Economy, vol.106(1998)1113-1155.

10. Z. Zheng, H. Deng, Legal environment difference and determinants of regional financial development, financial development based on the investigation of the provincial panel data of , J. Management World, vol.14(2010)14-27.

11. L.Chu, B.Y. Liu, The Relationship between Legal environment and Regional Insurance-Based on the Varied Economic Development level in China, J. Collected Essays on Finance and Economics, vol.3( February 2015)50-57. 